\title{
Persepsi Masyarakat Terhadap Penegakan Hukum Tindak Pidana Korupsi Di Kota Samarinda (Studi Di Kelurahan Pelabuhan Kota Samarinda)
}

\author{
Wahyuni Safitri, Rustiana \\ wahyunibun@gmail.com,rustiana77@gmail.com \\ Dosen Fakultas Hukum Universitas Widya Gama Mahakam Samarinda
}

\begin{abstract}
ABSTRAK
Korupsi merupakan salah satu masalah terbesar yang dihadapi oleh bangsa Indonesia khususnya kota Samarinda Kalimantan Timur. Banyak Orang yang tidak percaya lagi dengan penegakan hukum tindak pidana korupsi, dengan berbagai alasan kasus korupsi lepas dari tuntutan hukum membuat komponen masyarakat menjadi kehilangan kepercayaan terhadap penegakan hukum tindak pidana korupsi. Dampak yang dilahirkan akibat korupsi sangat berbahaya yang berakibat pada perkonomian dan pembangunan negara secara nasional. Jenis penelitian yang digunakan dalam tulisan ini adalah metode pendekatan empiris yang merupakan pendekatan yang relevan dengan permasalahan yang diteliti yaitu pendekatan langsung ke Masyarakat. Sehingga dapat memperoleh gambaran tentang persepsi masyarakat terhadap penegakan hukum tindak pidana korupsi dan kendala pelaksanaan penegakan hukum tindak pidana korupsi di kota samarinda. Berdasarkan hasil dan luaran yang dicapai dalam program penelitian adalah khususnya teruntuk masyarakat RT 29 Kelurahan Pelabuhan Kecamatan Samarinda Kota adalah pemahaman masyarakat yang ingin diketahui meliputi kesadaran (awareness), pengetahuan (knowledge), dan sikap (attitude) serta perilaku (behavior) masyarakat mengenai tindak pidana korupsi. Analisis dari tulisan ini menunjukan bahwa masyarakat banyak yang belum begitu mengerti dan paham mengenai penegakan hukum tindak pidana korupsi. Gambaran hasil dari kegiatan survey ini diharapkan dapat dijadikan masukan dan saran yang dapat membantu mengembangkan strategi yang efektif dalam memberantas korupsi serta peran masyarakat sebagai pengawas.
\end{abstract}

Kata Kunci :Persepsi, Penegakan, Tindak Pidana Korupsi 


\begin{abstract}
Corruption is one of the biggest problems faced by the Indonesian people, especially the city of Samarinda, East Kalimantan. Many people no longer believe in the enforcement of criminal acts of corruption, with a variety of reasons for corruption cases apart from lawsuits making the community component lose confidence in the enforcement of criminal acts of corruption. The impact caused by corruption is very dangerous which results in national economic and national development. The type of research used in this paper is an empirical approach which is an approach that is relevant to the problem under study, namely a direct approach to the community. So that it can get a picture of people's perceptions of corruption law enforcement and obstacles to the implementation of corruption law enforcement in the city of samarinda. Based on the results and outcomes achieved in the research program is specifically for the community RT 29 Port Village, City Samarinda Districtsis the understanding of the community that you want to know includes awareness, knowledge, and attitude and behavior of the community regarding criminal acts of corruption. Analysis of this paper shows that many people do not understand and understand the law enforcement of corruption. The description of the results of this survey activity is expected to be used as input and suggestions that can help develop effective strategies in combating corruption and the role of the community as supervisors.
\end{abstract}

Keywords: Perception, Enforcement, Corruption

\title{
PENDAHULUAN
}

\section{A. Latar Belakang}

Indonesia merupakan salah satu negara yang sedang berkembang sebagai negara yang sedang berkembang pada umumnya dihadapkan dengan berbagai masalah sosial. Salah satu masalah yang cenderung terjadi pada negara yang sedang berkembang adalah korupsi. Tidak hanya di indonesia dan negara-negara berkembang lainnya, akan tetapi di negara-negara maju pun korupsi menjelma menjadi virus yang mampu merusak sendi-sendi kehidupan berbangsa dan bernegara.

Persoalan korupsi tidak hanya melibatkan pejabat publik, pemerintah, swasta dan pegawai negeri yang menyalahgunakan kewenangan akan tetapi juga perorangan seperti calo tiket pesawat, kapal air, dan sebagainya. Hal tersebut menunjukkan bahwa perbuatan korupsi hanya dilakukan olah orang-orang tertentu saja.
Berdasarkan data yang diperoleh dari Pengadilan Tindak Pidana Korupsi (TIPIKOR) Samarinda, daerah yang banyak terdapat kasus korupsi adalah di Kota Samarinda Kalimantan Timur. Oleh karena itu perlu mengadakan peraturan yang dapat memberikan keleluasaan kepada pelaksana atau penegak hukum bertindak terhadap pelaku-pelaku tersebut. Hal ini dilakukan karena di dalam prakteknya, peraturan yang telah ada itu kurang efektif, sehingga perlu dilengkapi dengan peraturan lainnya, yaitu peraturan penilikan harta benda.

Korupsi merupakan kejahatan luar biasa karena menyebabkan terjadinya kerugian negara dan melanggar hak-hak sosial dan ekonomi masyarakat. Modus yang digunakan juga semakin beragam dan canggih. Oleh karena itu dikeluarkan Undang-Undang No. 30 Tahun 2002 yang menjadi dasar pembentukan Komisi 
Pemberantasan Korupsi (KPK) untuk melakukan tugas pemberantasan korupsi di Indonesia. ${ }^{1}$ Pemberantasan korupsi tidak dapat dilakukan oleh KPK dan penegak hukum saja, tetapi juga memerlukan sinergi dan kesamaan persepsi dari seluruh komponen bangsa. Di sini, peran serta masyarakat memiliki arti penting dalam strategi pemberantasan korupsi. Pada kegiatan yang sifatnya represif, masyarakat dapat langsung menjadi pelapor dugaan tindak pidana korupsi terutama di birokrasi dan layanan publik, sedangkan dari sisi preventif, tindakan utama pemberantasan korupsi dapat dimulai dari kesadaran diri masing-masing. Untuk mematuhi hukum dan menjauhi tindakan koruptif, Masyarakat pada umumnya anti korupsi, namun pada realitanya seringkali melakukan tindakan yang koruptif atau dimanfaatkan oleh pihak-pihak tertentu untuk menjadi lahan korupsi. Sebagai lembaga publik yang dibentuk untuk melaksanakan tugas pemberantasan korupsi sebagaimana dimaksud dalam Undang-Undang No. 30 Tahun 2002, Komisi Pemberantasan Korupsi (KPK) diwajibkan untuk mempertanggung jawabkan kinerjanya kepada publik.

Selain pelaporan ke Dewan Perwakilan rakyat (DPR) dan audit Badan Pemeriksa Keuangan (BPK), Komisi Pemberantasan Korupsi (KPK) juga perlu mengetahui persepsi dan harapan masyarakat terhadap kinerja dan capaian sebagai salah satu wujud mekanisme pengawasan lembaga publik oleh masyarakat.

Untuk itu Komisi Pemberantasan Korupsi (KPK) secara berkala melakukan survei yang ditujukan untuk mendapatkan

\footnotetext{
${ }^{1}$ Direktorat Penelitian dan Pengembangan 2009, Laporan Survei Persepsi Masyarakat 2009, Komisi Pemberantasan Korupsi (KPK), Jakarta, Hal.1
}

pemahaman mengenai persepsi dan harapan masyarakat terhadap korupsi dan KPK.

\section{B. Rumusan Masalah}

1. Bagaimana Persepsi Masyarakat terhadap Penegakan Hukum Tindak Pidana Korupsi di Kota Samarinda?

2. Apa saja yang menjadi kendala pelaksanaan Penegakan Hukum Tindak Pidana Korupsi di Kota Samarinda?

\section{Tujuan Penelitian}

1. Untuk mengidentifikasi pelaksanaan Penegakan Hukum Tindak Pidana Korupsi di Kota Samarinda.

2. Untuk mengidentifikasi dan menganalisa faktor-faktor yang menjadi kendala bagi Penegakan Hukum Tindak Pidana Korupsi di Kota Samarinda.

\section{Manfaat Penelitian}

Adapun Penelitian ini diharapkan memberikan manfaat baik secara Akademisi, dan juga pemerintahan. Secara Akademisi Penelitian ini diharapkan Sebagai bahan kajian dan menambah pemahaman terhadap perkembangan hukum di Indonesia khususnya bagi akademisi. Dan bagi Pemerintah diharapkan Sebagai bahan masukan bagi pemerintah dalam melaksanakan penegakan Hukum Tindak Pidana Korupsi dan mewujudkan pemerintahan yang bersih dan bebas korupsi di Kota Samarinda.

\section{METODE PENELITIAN}

\section{A. Jenis Penelitian}

Penelitian ini merupakan penelitian pendekatan empiris yaitu hukum sebagai kenyataan sosial, kultural atau das sein, karena dalam penelitian ini digunakan data primer yang diperoleh dari lapangan. Pendekatan yuridis adalah hukum dilihat 
sebagai norma atau das sollen, karena dalam membahas permasalahan penelitian ini menggunakan bahan-bahan hukum baik hukum yang tertulis maupun hukum yang tidak tertulis atau baik bahan hukum primer maupun bahan hukum sekunder. Jadi, pendekatan yuridis empiris dalam penelitian ini maksudnya adalah bahwa dalam menganalisis permasalahan dilakukan dengan cara memadukan bahanbahan hukum (yang merupakan data sekunder dengan data primer yang diperoleh di lapangan yaitu tentang Persepsi Masyarakat terhadap Penegakan Hukum Tindak Pidana Korupsi

Adapun Penelitian ini berlokasi di wilayah Kelurahan Pelabuhan Samarinda.

Adapun Jenis dan Sumber Data yang akan dikumpulkan dalam penelitian ini bersumber dari beberapa jenis data yaitu: Data primer adalah merupakan data yang diperoleh secara langsung dari pengamatan atas obyek atau permasalahan yang penulis amati di lokasi penelitian yaitu melalui wawancara langsung dengan pihak-pihak yang bersangkutan dan berkompeten dalam bidang yang berhubungan dengan permasalahan yang diangkat yakni yang berkaitan dengan Persepsi Masyarakat Terhadap Penegakan Hukum Tindak Pidana korupsi Di Kota Samarinda. Data Sekunder yaitu data yang diperoleh dari peraturan perundang - undangan studi kepustakaan terhadap jurnal, artikel dalam majalah atau sumber-sumber lain yang terkait dengan permasalahan yang dibahas dalam penulisan ini. Dan Data Tersier yaitu bahan hukum yang diperoleh dari Ensiklopedia, kamus dan lain - lain.

Adapun Teknik Pengumpulan data yang digunakan dalam penulisan ini yaitu meliputi: Wawancara adalah metode yang menggunakan teknik mewawancarai nara sumber yang dijadikan objek atau bahan penelitian guna mendapatkan hasil atau data yang diinginkan. Studi Pustaka Dalam penelitian ini, penulis mempelajari dan mengkaji perundang-undangan, jurnal, literatur, atau dokumen-dokumen yang berkaitan dengan Persepsi Masyarakat Terhadap Penegakan Hukum Tindak Pidana Korupsi Di Kota Samarinda. Dan Studi Dokumentasi Dalam penelitian ini, dokumentasi terkait dokumen-dokumen yang diperoleh oleh penulis di lokasi penelitian dan digunakan sebagai penunjang penelitian.

Teknik Sampling dalam Penelitian ini yaitu Probability sampling adalah teknik pengambilan sampel yang memberikan peluang yang sama bagi setiap unsur (anggota) populasi untuk dipilih menjadi anggota sampel. Syarat utama probability sampling dilakukan adalah sample diambil dari populasi yang homogen. Ramdom sampilng atau dalam bahasa Indonesia disebut juga Rambang hendaknya memberikan gambaran bahwa distribusi data pada populasi akan berlaku secara sembarang pada setiap anggota dari populasi.

Khususnya Simple Random Sampling Dikatakan simple (sederhana) karena pengambilan anggota sampel dari populasi dilakukan secara acak tanpa memperhatikan strata yang ada dalam populasi itu. Cara demikian dilakukan bila anggota populasi dianggap homogen atau memiliki kesamaan. Dengan demikian, anggota populasi yang dipilih akan mampu mewakili kondisi populasi. Karena itulah peneliti mengunakan teknik ini sebagai acuan dalam menggambil sampel.

Adapun Teknik Analisi Data dalam Penelitian ini yaitu dari hasil penelitian yang terkumpul seperti yang diperoleh dari lapangan dan data kepustakaan, maka selanjutnya data tersebut di analisa secara 
deskriptif kualitatif. Deskriptif kualitatif artinya menggambarkan secara jelas dan sistematis seluruh data yang telah diperoleh dan kemudian akan dianalisis terhadap kebutuhan hukum dalam hal implementasi perencanaan pembangunan desa dan kemudian data tersebut akan disajikan dengan memberikan komentar-komentar.

\section{Hasil Penelitian Dan Pembahasan}

\section{HASIL PENELITIAN}

Kota Samarinda dibentuk dan didirikan pada tanggal 21 Januari 1960, berdasarkan UU Darurat No. 3 Tahun 1953, Lembaran Negara No. 97 Tahun 1953 tentang Pembentukan daerah - daerah Tingkat II Kabupaten/kotamadya di Kalimantan Timur. Secara administratif Kota Samarinda memiliki 10 kecamatan dan 59 kelurahan. Peresmian kecamatan tersebut dilaksanakan pada tanggal 28 Desember $2010 .{ }^{2}$ Hingga hari ini, praktek korupsi masih menjadi isu utama di negeri ini khususnya di kota samarinda. Korupsi telah terjadi disemua aspek kehidupan masyarakat dan mewabah ke cabang kekuasaan eksekutif, legislatif dan yudikatif, serta sektor bisnis.Hampir setiap hari media masa baik nasional maupun lokal memberitakan isu atau masalah korupsi. Akibat korupsi yang semakin tinggi , masyarakat secara sadar atau tidak sadar telah menjadi korban utama sementara negara menanggung kerugian material dan non- material yang sangat besar. Tingginya keadaan korupsi di samarinda dapat dilihat dari penelitian dan survei hasil kuisioner masyarakat dikelurahan pelabuhan kota samarinda yang dilaksanakan pada tanggal 04 Juni 2018, yang melibatkan 50 (lima puluh) responden yang terdiri dari berbagai latar belakang

https://id.wikipedia.org/wiki/Daftar_kecamatan _dan_kelurahan_di_Kota_Samarinda pendidikan mulai dari tingkat SD, SMA, dan mahasiswa. Dari seluruh responden, responden yang paling besar adalah responden dengan pendidikan tamat SMA (42\%),tamat SD (33\%)dan mahasiswa (25\%).Melalui survei ini, diharapkan dapat mengetahui sejauh mana masyarakat memiliki pengetahuan/pemahaman yang memadai terhadap definisi dan tindakantindakan koruptif yang umum terjadi di sekitar lingkungan mereka.

Berikut kuisioner yang dibagikan kepada masyarakat kelurahan pelabuhan kota samarinda.

Warga : Kelurahan Pelabuhan,

RT.

Pendidikan : SD/ SMP/ SMA/

SARJANA

Jenis Kelamin : LK/PR

Kuisioner Penelitian

Persepsi MasyarakatTerhadap Penegakan Hukum Terkait Kasus Korupsi di Kota Samarinda.

1. Kurang adanya teladan dari pimpinan pemerintah menyebabkan seseorang melakukan tindak pidana korupsi

a. Setuju

b. Kurang Setuju

c. Tidak Setuju

d.

2. Sistem

Akuntabilitas/ pertanggungjawaban yang kurang memadai memberi peluang untuk melakukan korupsi

a. Setuju

b. Kurang Setuju

c. Tidak Setuju

d.

3. Manajemen yang tidak transparan/ keterbukaan cenderung menutupi korupsi di dalam instansi pemerintah 

a. Setuju
b. Kurang Setuju
c. Tidak Setuju
d.

4. Adanya korupsi di sebabkan karena Birokrasi yang panjang dan berbelitbelit

a. Setuju

b. Kurang Setuju

c. Tidak Setuju

d.

5. Pelayanan publik yang rendah memberi peluang untuk melakukan korupsi.

a. Setuju

b. Kurang Setuju

c. Tidak Setuju

d.

6. Korupsi disebabkan karena lemahnya system pengendalian instansi pemerintah

a. Setuju

b. Kurang Setuju

c. Tidak Setuju

d.

7. Peraturan perundang-undangan yang monolistik (Kepercayaan terhadap Sesuatu secara Keseluruhan/ Hanya Mempercayai 1 Hal) dan menguntungkan kerabat menjadi peluang untuk melakukan korupsi

a. Setuju

b. Kurang Setuju

c. Tidak Setuju

d.

8. Kualitas perundang-undangan yang tidak memadai menyebabkan korupsi tinggi

a. Setuju

b. Kurang Setuju

c. Tidak Setuju

d.
9. Seseorang melakukan korupsi karena sanksi yang dijatuhkan sangat ringan

a. Setuju

b. KurangSetuju

c. TidakSetuju

d.

10.Korupsi terjadi karena penerapan sanksi yang tidak konsisten dan pandang bulu

a. Setuju

b. Kurang Setuju

c. Tidak Setuju

d.

11.Lemahnya bidang evaluasi dan revisi perundang-undangan menyebabkan korupsi semakin tinggi

a. Setuju

b. Kurang Setuju

c. Tidak Setuju

d.

12.Korupsi terjadi karena masyarakat lemah dalam melakukan pengawasan

a. Setuju

b. Kurang Setuju

c. Tidak Setuju

d.

13.Korupsi disebabkan karena tidak ada mekanisme pengawasan yang dapat dipertanggungjawabkan

a. Setuju

b. Kurang Setuju

c. Tidak Setuju

d.

14.Lembaga peradilan yang tidak independen membuat seseorang berani melakukan korupsi

a. Setuju

b. KurangSetuju

c. TidakSetuju

d. 
15.Bentuk tindak korupsi bias berupa pengeluaran anggaran yang tidak sesuai dengan prioritas pembangunan

a. Setuju

b. Kurang Setuju

c. Tidak Setuju

d.

16.Menurut Anda, Apakah Korupsi merupakan Masalah Utama yang Terjadi di Indonesia ?

a. Masalah Utama

b. Bukan Masalah Utama

c. Bukan Masalah

d.

17. Menurut Anda, dimanakah Korupsi yang Paling Umum terjadi ?

a. Lembaga Daerah

b. Lembaga Penegak Hukum

c. Lembaga Negara

d.

18. Menurut Anda, Manakah Lembaga yang Paling Anda Andalkan dalam Pemberantasan Korupsi ?

a. Komisi Pemberantasan Korupsi

b. Kejaksaan

c. Kepolisian

d.

19.Menurut Anda, apa yang menjadi Hambatan Terbesar dalam Memberantas Korupsi yang terjadi saat ini ?

a. Kurangnya Wewenang dan Sumber Daya yang ada di KPK

b. Kurangnya Pendidikan terhadap Anti Korupsi

c. Maraknya Kriminalisasi

d.

20.Menurut Anda, Bagaimanakah Penyelesaian Permasalahan terhadap Korupsi ?

a. Peningkatan Hukuman bagi Koruptor b. Peningkatan Kerjasama Antar Penegak Hukum

c. Kedua - duanya

d.

21.Menurut Anda, Mengapa Korupsi Bisa Terjadi?

a. Karena Kebutuhan

b. Karena Adanya Peluang

c. Karena Ingin Memperkaya Diri Sendiri

d.

22.Menurut Anda, Apa yang dilakukan guna Memberikan Efek Jera bagi Koruptor ?

a. Hukuman Diperberat

b. Dimiskinkan

c. Dikucilkan

d.

23.Menurut Anda, BagaimanaSolusi yang Baik bagi Tindakan Korupsi ?

a. Sistem Penegakan Hukum harus diperbaiki

b. Menanamkan Nilai Anti Korupsi Sejak Dini

c. Menyebarkan dan Mensosialisasikan Anti Koruspi kepada Masyarakat

d.

24.Harapan Anda terhadap Penegakan dan Pemberantasan Korupsi saat ini?

a. Berkurang

b. Meningkat

c. Biasa Saja

d.

25.Menurut Anda, Bagaimana agar Seseorang Terhindar dari Perbuatan Korupsi ?

a. Penanaman Pendidikan Moral dan Agama Sejak Dini

b. Menumbuhkan Kesadaran Diri bahwa Korupsi $=$ Mencuri

c. Menanamkan Kesadaran Bahwa Korupsi sangan Merugikan 
d.

Kritik dan Saran :

Melalui survei ini, diharapkan dapat mengetahui sejauh mana masyarakat memiliki pengetahuan/pemahaman yang memadai terhadap definisi dan tindakantindakan koruptif yang umum terjadi di sekitar lingkungan mereka Dalam survei ini dipilih 5 (Lima) pernyataan yang dekat dengan kehidupan sehari-hari masyarakat, sehingga responden dapat dengan cepat memberikan jawaban mengenai persepsi dari pernyataan tersebut. Secara umum, masyarakat cukup menyadari adanya bentuk perilaku koruptif dalam kehidupan mereka, dan tidak setuju dengan perbuatan tersebut.

Kuisioner Persepsi Masyarakat Terhadap Penegakan Hukum TIPIKOR.

1. Seseorang melakukan korupsi karena sanksi yang dijatuhkan sangat ringan

2. Korupsi terjadi karena masyarakat lemah dalam melakukan pengawasan

3. Menurut Anda, Manakah Lembaga yang Paling Anda Andalkan dalam Pemberantasan Korupsi

4. Menurut Anda, Apa yang dilakukan guna Memberikan Efek Jera bagi Koruptor

5. Menurut Anda, Bagaimana Solusi yang Baik bagi Tindakan Korupsi

\section{Sanksi Terhadap Korupsi}

घ Setuju $\quad$ Kurang Setuju $\quad$ Tidak Setuju

$09 \%$

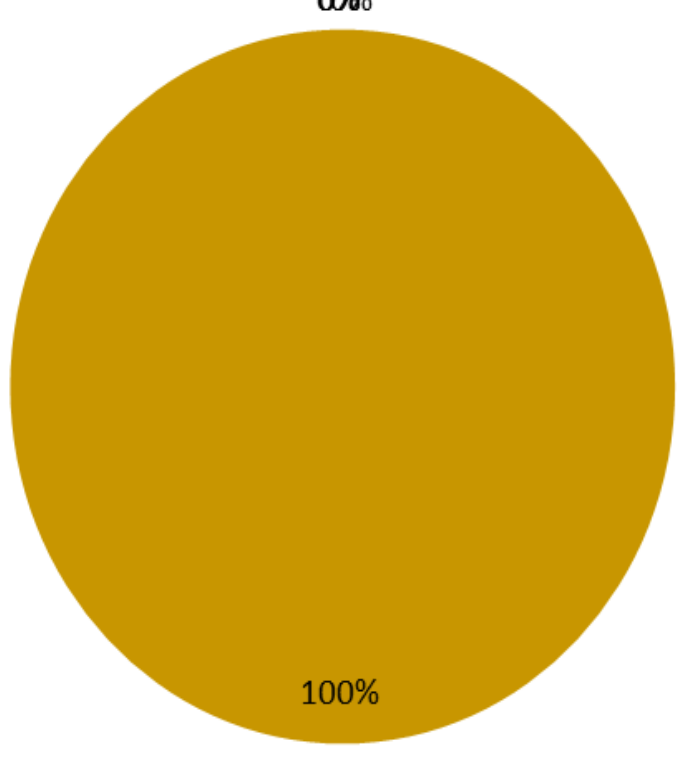




\section{Pengawasan Masyarakat Yang Lemah} Terhadap Korupsi

- Setuju $\quad$ Kurang Setuju $\quad$ Tidak Setuju

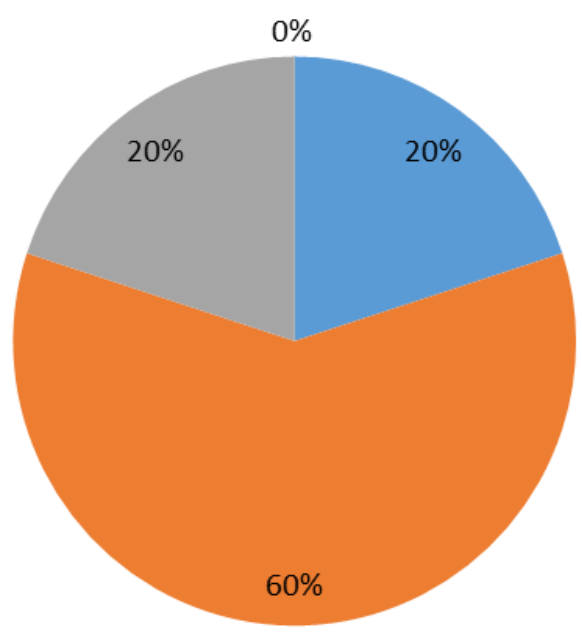

Lembaga Paling Diandalkan Dalam Pemberantasan Korupsi

- KPK $\square$ Kejaksaan $\quad$ Kepolisian

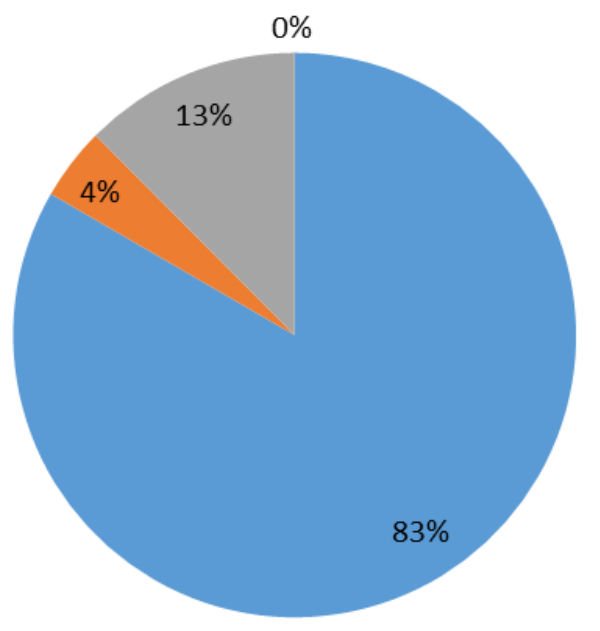




\title{
Solusi Bagi Tindakan Korupsi
}

\author{
— Sistem Hukum Diperbaiki \\ घ Menanamkan Nilai Anti Korupsi Sejak Dini \\ - Menyebarkan Dan Mensosialisasikan Anti Korupsi Kepada Masyarakat
}

$\square$

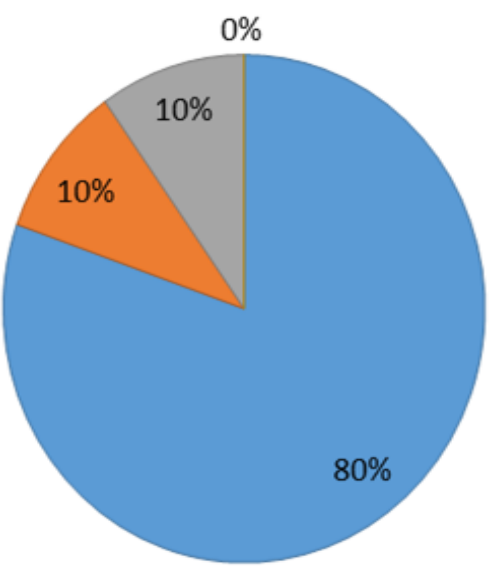

- Dari hasil survei ini masyarakat nampaknya cukup mendukung upaya peningkatan transparansi penyelenggara negara khususnya mengenai kekayaan negara.

- Kekayaan pejabat dan penyelenggara negara merupakan hal sensitif yang umumnya menjadi perhatian masyarakat Peningkatan kekayaan yang signifikan dan tidak bisa dibuktikan, dianggap $95 \%$ responden sebagai korupsi.

\section{PEMBAHASAN PENELITIAN}

\section{Persepsi Masyarakat Terhadap Penegakan Hukum Tindak Pidana Korupsi di Kota Samarinda.}

a. Penegakan Hukum Tindak Pidana Korupsi.

Penegakan hukum di Indonesia khususnya di Kota Samarinda selalu menjadi objek yang menarik untuk dikaji baik pada masa Orde Lama, orde baru maupun orde yang sekarang ini sedang berjalan yang biasa disebut dengan orde reformasi. Khusus dalam penegakan hukum terhadap tindak pidana korupsi terdapat berbagai lembaga yang mempunyai kewenangan untuk melakukan penyidikan terhadap tindak pidana tersebut. Lembaga-lemabaga tersebut diantaranya lembaga kepolisian, kejaksaan dan Komisi Pemberantasan Tindak Pidana Korupsi (selanjutnya disebut KPK). Penegakan hukum terhadap tindak pidana korupsi sangat berbeda dengan tindak pidana yang lain, diantaranya karena banyaknya lembaga yang berwenang untuk melakukan proses peradilan terhadap tindak pidana korupsi sebagaimana telah di sebutkan dalam alenia pertama. Kondisi demikian merupakan konsekuensi logis dari predikat yang di letakkan pada tindak pidana tersebut sebagai extra ordinary crime (kejahatan luar biasa). Sebagai tindak pidana yang dikategorikan sebagai extra ordinary crime tindak pidana korupsi 
mempunyai daya hancur yang luar biasa dan merusak terhadap sendi-sendi kehidupan suatu negara dan bangsa.

Dampak dari tindak pidana korupsi dapat dilihat dari terjadinya berbagai bencana alam dan kerusakan lingkungan seperti banjir, bahkan Nyoman Serikat Putra Jaya mengatakan bahwa akibat negatif dari adanya tindak pidana korupsi sangat merusak tatanan kehidupan bangsa, bahkan korupsi merupakan perampasan hak ekonomi dan hak sosial masyarakat Indonesia. ${ }^{3}$ Penegakan hukum dapat diartikan dalam arti sempit "law enfocement" sedangkan penegakan hukum dalam arti hukum materii diartikan dengan penegakan keadilan. Dalam bahasa inggris dibedakan antara konsepsi "court of law" dalam arti pengadilan hukum dan "court of justice" atau pengadilan keadilan. ${ }^{4}$ Aktivitas para penegak hukum khususnya penegakan hukum terhadap tindak pidana korupsi tidak selalu sesuai dengan harapan. Konfigurasi politik suatu negara akan mempengaruhi aktifitas penegak hukum dalam melakukan penegakan hukum. Hal ini disebabkan penegakan hukum terhadap tindak pidana korupsi selalu melibatkan penyelenggara negara atau pejabat negara.

Hal ini berbeda apabila para pihaknya adalah orang biasa dalam hal ini penegak hukum lebih bebas untuk mengekpresikan kewenangannya dalam menegakkan keadilan dan hukum. Dalam hal salah satu pihaknya negara atau pejabat negara penegak hukum akan ekstra hatihati dalam menggunakan kewenangannya sehingga akan timbul kesan lambat, tebang pilih dan sebagainya. Dalam kondisi demikian asas Equality Before the Law akan dibuktikan kebohongannya, dan

\footnotetext{
${ }^{3}$ Nyoman Sarekat Putra Jay,. 2008, Beberapa Pemikiran ke arah Pengembangan Hukum Pidana, Citra Aditya Bakti, Bandung, Hal. 69.

${ }^{4}$ Djarot M.Subroto, 2001, Peran polisi dalam pembangunan, Sinar Persada, Jakarta, hal.63
}

hanya akan dipercaya sebagai sebuah mitos belaka. Berkaitan dengan hal ini Romli Atmasasmita menyatakan:

Dampak negatif dari keadaan di atas adalah muncul fenomena ambivalensi sikap dan perilaku pejabat pemerintahan dan bahkan penegak hukum dalam menjalankan kewajibannya menaati hukum dan menegakan hukum. Berbagai kasus korupsi yang menyangkut pejabat tinggi dan mereka yang dekat dengan kekuasaan ditindak lanjuti secara selektif dan menampakkan diskriminasi secara terbuka, resistensi terhadap agenda pemberantasan korupsi mulai tumbuh seperti jamur di musim hujan, mulai dari lontaran keresahan pejabat daerah dan calon pemimpin proyek sampai kepada gagasan untuk membubarkan Komisi Pemberantasan Korupsi dan mengurangi peranan lembaga Negara yang ditugasi melakukan pengawasan terhadap kinerja pemerintah. ${ }^{5}$ Korupsi merupakan salah satu tindak pidana yang tidak dapat dilepaskan dari masalah negara, pejabat negara atapun orang-orang yang mempunyai kedudukan terhormat di dalam masyarakat. Untuk mewujudkan penyelenggaraan negara yang bersih dan bebas dari KKN bukan hanya tanggung jawab dari penyelenggara negara tapi juga masyarakat dan komponen bangsa. Dari hasil evaluasi menunjukan bahwa kinerja KPK memiliki sejumlah catatan baik positif dan negatif. Kinerja KPK yang dapat dinilai sebagai catatan positif antara lain KPK sudah mulai menanggani kasus korupsi disektor yang dikehendaki masyarakat (Korupsi politik, korupsi peradilan, korupsi perbankan) KPK juga mulai memberikan perhatian untuk menangani korupsi didaerah khususnya samarinda terbukti persepsi masyarakat

\footnotetext{
${ }^{5}$ Atmasasmita, Romli, 2008, Arah Pembangunan Hukum di Indonesia, dalam Komisi Yudisial dan Keadilan Sosial, Komisi Yudisial. Hal.116.
} 
melalui kuisioner terkait dengan lembaga yang paling di andalkan dalam pemberantasan kasus korupsi adalah lembaga independen yaitu KPK.

\section{Kendala Pelaksanaan Penegakan Hukum Tindak Pidana Korupsi di Kota Samarinda.}

\section{a. Penyelenggara Kekuasaan Pemerintah Daerah. \\ Dalam kehidupan tatanan bernegara} hukum mengatur dan diperlukan hampir pada semua prilaku masyarakat.Soerjono soekanto bahwa agar hukum itu berfungsi dimasyarakat diperlukan adanya keserasian antara empat faktor yakni, pertama adanya sinkronisasi yang sistematis diantara kaidah - kaidah hukum atau peraturan baik vertical maupun horizontal sehingga tidak bertentangan satu sama lain; kedua pelaksana penegak hukum mempunyai pedoman yang jelas tentang kewenangannya dalam menjalankan tugas, sekaligus kualitas kepribadian petugas untuk melaksanakan dan mentaati peraturan yang diberlakukan; ketiga derajat kepatuhan hukum masyarakat terhadapa hukum sangat mempengaruhi pelaksanaan hukum. Derajat kepatuhan hukum ini tergantung pada proses pembuatan hukum ; keempat fasilitas atau sarana pendukung pelaksanaan hukum harus memadai secara fisik. $^{6}$ Pemerintah daerah sesuai kewenangannya dalam sistem pemerintah otonomi daerah maka perlu melakukan kerjasama dengan penegak hukum dan pihak lain yang konsen terhadap upaya pemberantasan tindak pidana korupsi didaerah, karena didaerah khususnya kota samarinda sudah sangat memprihatinkan perilaku korupsi. Satjipto Rahardjo merumuskan penegakan hukum sebagai suatu proses untuk mewujudkan keinginan - keinginan hukum menjadi kenyataan. Sajipto Raharjo mengemukakan bahwa ada tiga hal dalam prose penegakan hukum yaitu; unsur pembuat undang- undang, unsur aparat penegak hukum, unsur lingkungan yang meliputi pribadi warga negara dan sosial. $^{7}$ Memerangi tindak pidana korupsi diindonesia, Khususnya di kota Samarinda diperlukan komitmen penegakan hukum yang tegas, agar kejahatan tersebut tidak terus berkembang. Polisi, jaksa, advokad, dan masyarakat harus berkomitmen untuk memerangi dan memberantas korupsi di kota samarinda.

\section{b. Penguatan Pengawasan}

Pelaksanaan penguatan pengawasan yang intensif adalah Salah satu bentuk upaya untuk menekan angka korupsi diindonesia, bahwa pengawasan yang dilakukan adalah :

1. Peranan sistem pengendalian intern (pengawasan yang melekat)

2. Peranan pengawasan fungsional

3. Pengawasan legislative

4. Pengawasan masyaraka

Pemberantasan korupsi tidak akan dapat diatasi oleh penegak hukum saja, tetapi harus didukung oleh berbagai pihak yaitu mulai dari penegak hukum itu sendiri seperti KPK, Kejaksaan agung, Kepolisian, Advokad, dan yang paling penting dukungan masyarakat agar dapat melaporkan korupsi yang terjadi, dengan catatan laporan tersebut tidak didasarkan pada rasa dendam, iri dan dengki terhadap seseorang, tetapi laporan itu harus kongkrit dan dapat dipertanggungjawabkan secara hukum.

\footnotetext{
${ }^{6}$ Soerjono soekanto, 2005, Sosiologi Hukum Dalam masyarakat, Rajawali, Jakarta, Hal.15
} 
Masalah korupsi berkaitan erat dengan kompleksitas masalah lain, antara lain sikap mental dan moral, pola dan sikap hidup, serta budaya sosial, kebutuhan dan tuntutan ekonomi, struktur dan budaya politik, peluang yang ada didalam mekanisme pembangunan atau kelemahan birokrasi dibidang keuangan dan pelayanan umum. ${ }^{8}$ Dari pandangan diatas bahwa pemberantasan tindak pidana korupsi yang terjadi di kota samarinda di perlukan pengawasan ketat terhadap penyelenggara negara dan komponen masyarakat yang menggunakan keuangan negara.

\section{PENUTUP KESIMPULAN DAN SARAN}

Adapun Kesimpulan dalam Penelitian ini adalah Persepsi masyarakat terhadap penegakan hukum tindak pidana korupsi dikota samarinda bahwa masyarakat percaya dengan lembaga yang paling diandalkan didalam pemberantasan tindak pidana korupsi adalah KPK, sebagai wujud mekanisme pengawasan lembaga publik oleh masyarakat, lembaga yang lebih independen, lebih berani, memiliki wewenang besar, tidak tebang pilih dan berkinerja baik.

Diperlukan aparatur penegak hukum yang terlatih, jujur, berintegrasi dan profesional. Agar aparat-aparat penegak hukum tersebut dapat membongkar perkara-perkara korupsi dan berani menindak siapa saja yang salah.

Adapun Saran dalam Penelitian ini yaitu bahwa Masyarakat diharapkan memahami bahwa pemberantasan korupsi tidak hanya dilakukan dengan menangkapi para koruptor namun juga mengembalikan

\footnotetext{
${ }^{8}$ Barda Nawawi Arief, 2000, Beberapa Aspek Kebijakan Penegakan dan Pengembangan Hukum Pidana, Pt. citra Aditya Bakti, Bandung, Hal.72
}

uang negara, melakukan berbagai upaya pencegahan dan mengawal pelaksanaan reformasi birokrasi.

Di bidang pencegahan, salah satu yang populer adalah kampanye anti korupsi yang dilakukan KPK, dimana presentase responden yang mengetahui hal tersebut paling tinggi.

\section{DAFTAR PUSTAKA}

\section{Buku:}

Jalaludin, 2004, Psikologi Komunikasi, Jakarta, Citra AdityaBakti.

Koenjaraningrat, 2012,Pengantar Antropologi Hukum, Jakarta, Aksara Baru.

Raharjo Sajipto, 2006, Masalah Penegakan Hukum, Bandung, Sinar Baru.

Harun M. Husen, 2001, Kejahatan dan Penegakan Hukum Di Indonesia, Jakarta, Rineka Cipta.

Chazawi Adam, 2002, Pelajaran Hukum Pidana Bag.1, Jakarta, Raja Grafindo Persada.

M.Faal, 2000, Penyaringan Perkara Pidana Oleh Polisi (Deskresi kepolisian),

Andi Hamzah, 2005, Korupsi di Indonesia, Jakarta, Sinar Grafika.

Jay Nyoman Sarekat Putra, 2008, Beberapa Pemikiran kearah Pengembangan Hukum Pidana, Bandung, Citra Aditya Bakti. 
Djarot M. Subroto, 2001, Peran polisi dalam pembangunan, Jakarta,Sinar Persada.

Atmasasmita Romli, 2008, Arah Pembangunan Hukum di Indonesia, dalam Komisi Yudisial dan Keadilan Sosial, Komisi Yudisial.

Soerjono soekanto, 2005, Sosiologi Hukum Dalam masyarakat, Jakarta Rajawali.

Satjipto Rahardjo, 2006, Masalah Penegak Hukum, Bandung, Sinar Baru.

Arief Barda Nawawi, 2000, Beberapa Aspek Kebijakan Penegakan dan Pengembangan Hukum Pidana, Bandung, Pt. Citra Aditya Bakti.

Ensiklopedi Hukum Islam, 2003, Jakarta, PT. Ichtiar Baru Van Hoeve.

\section{Peraturan Perundang Undangan :}

Undang-Undang RI Nomor 31 Tahun 1999, 2003,Tindak Pidana Korupsi, Bandung, Citra Umbara.

Undang-UndangNomor 20 Tahun 2001 tentang Pemberantasan Tindak Pidana Korupsi.

\section{Internet :}

https://id.wikipedia.org/wiki/daftar_kecama tan_dan_kelurahan_di_kota_samarinda.

http://suaranuraniguru.wordpress.com/2011 /11/29/persepsi/ diaksestanggal 23 desember 2017 pukul 14.00. 